\title{
Hjerteinfarkt med dyspné har dårligere prognose
}

Hjerteinfarkt med dyspné som

hovedsymptom er assosiert med

fire ganger så høy dødelighet som

hjerteinfarkt med brystsmerter, viser ny studie.

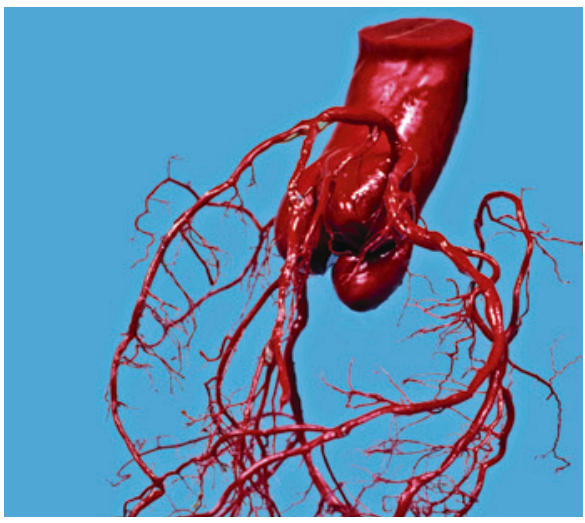

Illustrasjonsfoto: Science Photo Library
En dansk oppfølgingsstudie omfattet rundt 17400 pasienter som var vurdert i ambulanse med EKG grunnet mistanke om hjerteinfarkt (1). Man ønsket å sammenligne dødeligheten blant dem med dyspné som dominerende symptom $(8 \%)$ med dem som hadde brystsmerter som hovedsymptom (70\%). Pasientene med dyspné og bekreftet hjerteinfarkt hadde en 30-dagersdødelighet på $21 \%$ og fireårsdødelighet på $60 \%$ mot henholdsvis $5 \%$ og $23 \%$ hos pasienter med brystsmerter.

Forfatterne konkluderer med at man i videre studier bør undersøke om supplerende undersøkelser prehospitalt kan bedre behandlingen og dermed utfallet hos pasienter med dyspné.

- Dette er en imponerende studie med et stort datamateriale, sier professor Henrik Schirmer ved Universitetet i Troms $\varnothing$ - Norges arktiske universitet. - Artikkelen mangler opplysninger om tid fra symptomdebut og type hjerteinfarkt, begge er faktorer som kan medvirke til økt dødelighet. Lengre tid til revaskularisering medfører økt fare for irrever- sibel hjertesvikt, noe som kan gi laktatstigning og dyspné. Eldre har oftere hjerteinfarkt uten ST-elevasjon, som innebærer lengre tid til revaskularisering. $25 \%$ av disse pasientene har en akutt okklusjon som ikke ses på EKG. Studier har vist at dette er en av årsakene til at slike pasienter har høyere ettårsdødelighet enn pasienter med ST-elevasjonsinfarkt.

Kartlegging av respirasjonsfrekvens prehospitalt og i akuttmottak hos alle akuttpasienter vil sikre raskere identifisering av alvorlig syke pasienter og sikre muligheten for å gi mer målrettet behandling for å senke dødeligheten, sier Schirmer.

\section{Liv-Ellen Vangsnes \\ Tidsskriftet}

\section{Litteratur}

1. Bøtker MT, Stengaard C, Andersen MS et al. Dyspnea, a high-risk symptom in patients suspected of myocardial infarction in the ambulance? A population-based follow-up study. Scand J Trauma Resusc Emerg Med 2016; 24: 15.

\section{Har formidling av genetisk sykdomsrisiko noen effekt?}

\author{
Mange har spådd at medisinen står foran en ny æra med individualise- \\ ring av behandling basert på DNA-analyser, der spesifikke råd kan gis til \\ pasienter basert på genetisk risiko.
}

I en ny metaanalyse publisert i tidsskriftet $B M J$ gjennomgikk man 18 studier med randomisert og kvasirandomisert design, der voksne personer med økt genetisk risiko for sykdom ble gitt eller ikke gitt informasjon om sykdomsrisiko, forutsatt at risikoen kunne reduseres gjennom livsstilstiltak (1). Et eksempel var pasienter med økt genetisk risiko for malignt melanom og informasjon om sunne solvaner.

Formidling av genetisk risiko hadde ikke påvist effekt på røyking, matvaner, alkoholinntak, fysisk aktivitet eller annen potensielt helseskadelig atferd, sammenlignet med formidling av annen type risiko eller ingen formidling overhodet. Forfatterne understreker imidlertid at studiene hadde høy risiko for seleksjonsskjevhet, mange studier hadde for lav styrke til å kunne oppdage små effekter av intervensjon og kunnskapsgrunnlaget har derfor lav kvalitet. Forfatterne konkluderer med at effekten av kommunikasjon av DNAbasert risiko for sykdom i beste fall er liten.

- Disse funnene viser at det å formidle informasjon om genetisk risiko tilpasset det enkelte individ i seg selv ikke resulterer i at vedkommende endrer livsstil, sier Jan Frich, som er overlege ved Nevrologisk avdeling,
Oslo universitetssykehus og professor ved Universitetet i Oslo.

- Det har vært gjort en del forskning på ulike måter å dele informasjon om risiko. Hvordan kommunikasjonen foregår, har betydning. Artikkelen gir svært lite informasjon om hvilke format eller tilnærminger som ble brukt i de studiene som ble analysert, sier Frich. - Snarere enn å standardisere kommunikasjonen, bør det legges til rette for en samtale hvor man for eksempel benytter visuelle verktøy for kommunikasjon av risiko, der lege og pasient i fellesskap utforsker betydningen av informasjonen.

- Det å være kjent med genetisk risiko kan ha verdi i seg selv. En pasient vil kunne si takk for informasjonen, men samtidig velge ikke å gjøre endringer i måten han eller hun lever sitt liv. Det må vi ha forståelse for og respektere, mener Frich.

\section{Ketil Slagstad}

Tidsskriftet

\section{Litteratur}

1. Hollands GJ, French DP, Griffin SJ et al. The on risk-reducing health behaviour: systematic review with meta-analysis. BMJ 2016; 352: i1102. impact of communicating genetic risks of disease

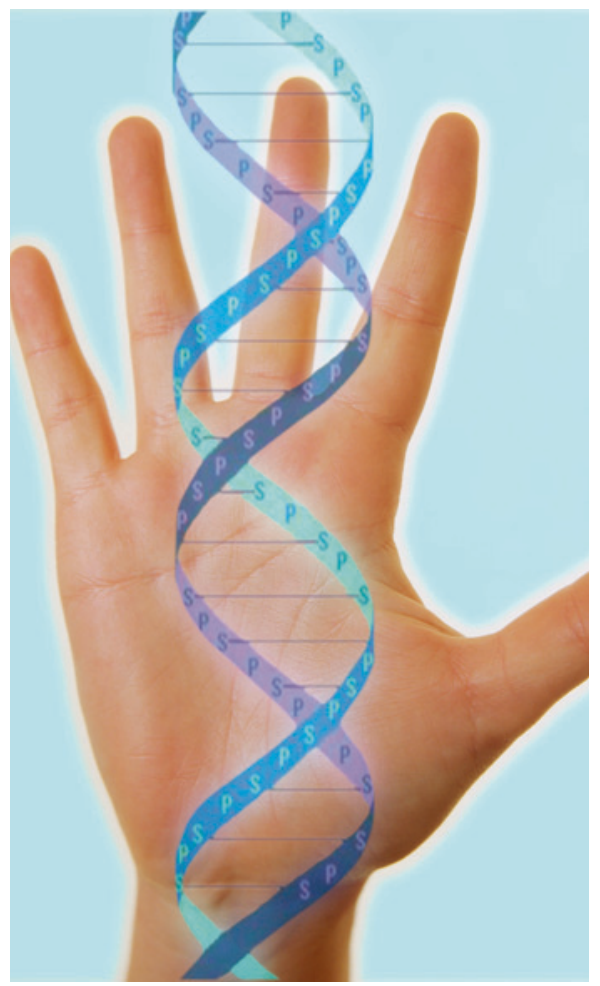

Illustrasjonsfoto: Science Photo Library 